RFP-2271

October 14, 1974

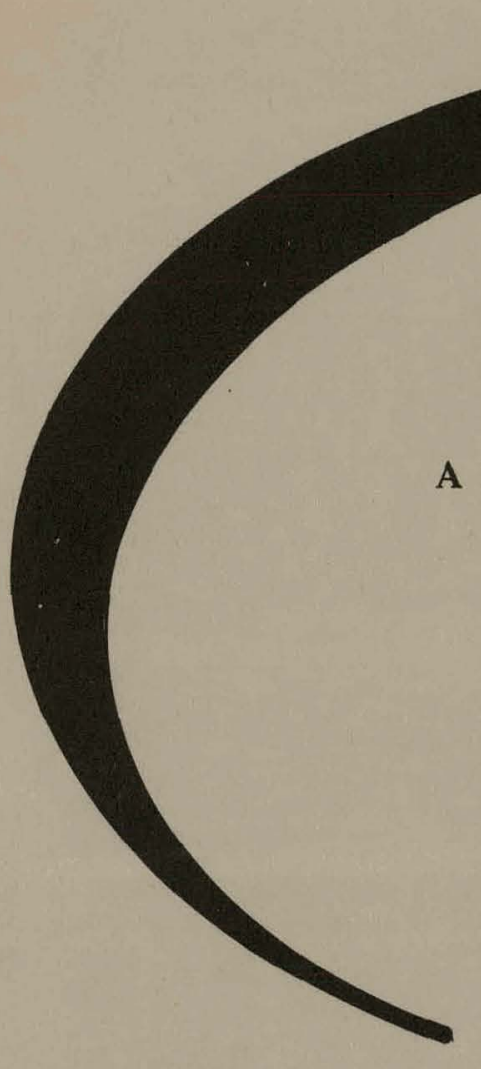

PILOT PLANT DEVELOPMENT OF

A FLUIDIZED BED INCINERATION PROCESS

Donald L. Ziegler

Andrew J. Johnson

Louis J. Meile

Alfred L. Johnston

Elmer L. Shamhart

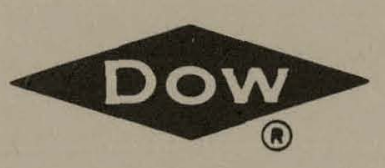

DOW CHEMICAL U.S.A. ROCKY FLATS DIVISION

P. O. BOX 888

GOLDEN, COLORADO 80401

U. S. ATOMIC ENERGY COMMISSION CONTRACT AT(29-1)-1106 


\section{DISCLAIMER}

This report was prepared as an account of work sponsored by an agency of the United States Government. Neither the United States Government nor any agency Thereof, nor any of their employees, makes any warranty, express or implied, or assumes any legal liability or responsibility for the accuracy, completeness, or usefulness of any information, apparatus, product, or process disclosed, or represents that its use would not infringe privately owned rights. Reference herein to any specific commercial product, process, or service by trade name, trademark, manufacturer, or otherwise does not necessarily constitute or imply its endorsement, recommendation, or favoring by the United States Government or any agency thereof. The views and opinions of authors expressed herein do not necessarily state or reflect those of the United States Government or any agency thereof. 


\section{DISCLAIMER}

Portions of this document may be illegible in electronic image products. Images are produced from the best available original document. 


\section{LEGAL NOTICE}

This report was prepared as an account of work sponsored by the United States Government. Neither the United States nor the United States Atomic Energy Commission, nor any of their employees, nor any of their contractors, subcontractors, or their employees, makes any warranty, expressed or implied, or assumes any legal liability or responsibility for the accuracy, completeness or usefulness of any information, apparatus, product or process disclosed, or represents that its use would not infringe privately owned rights.

Printed in the United States of America

Available from the

National Technical Information Service

U. S. Department of Commerce

Springfield, Virginia 22151

Price: Printed Copy $\$ 4.00$ Microfiche $\$ 1.45$ 


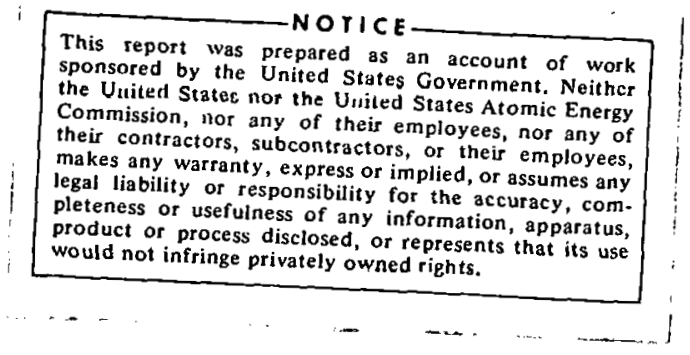

PILOT PLANT DEVELOPMENT OF

A FLUIDIZED BED INCINERATION PROCESS

Doriald L. Ziegler

Andrew J. Johnson

Louis J. Meile

Alfred L. Johnston

Elmer L. Shamhart

Chemistry Research and Development

PILOT PLANT DEPARTMENT

DOW CHEMICAL U.S.A.

ROCKY FLATS DIVISION

P. O. BOX 888

GOLDEN, COLORADO 80401

Prepared under Contract AT(29-1)-1106

for the

Albuquerque Operations Office

U. S. Atomic Energy Commission 
RFP-2271 


\section{CONTENTS}

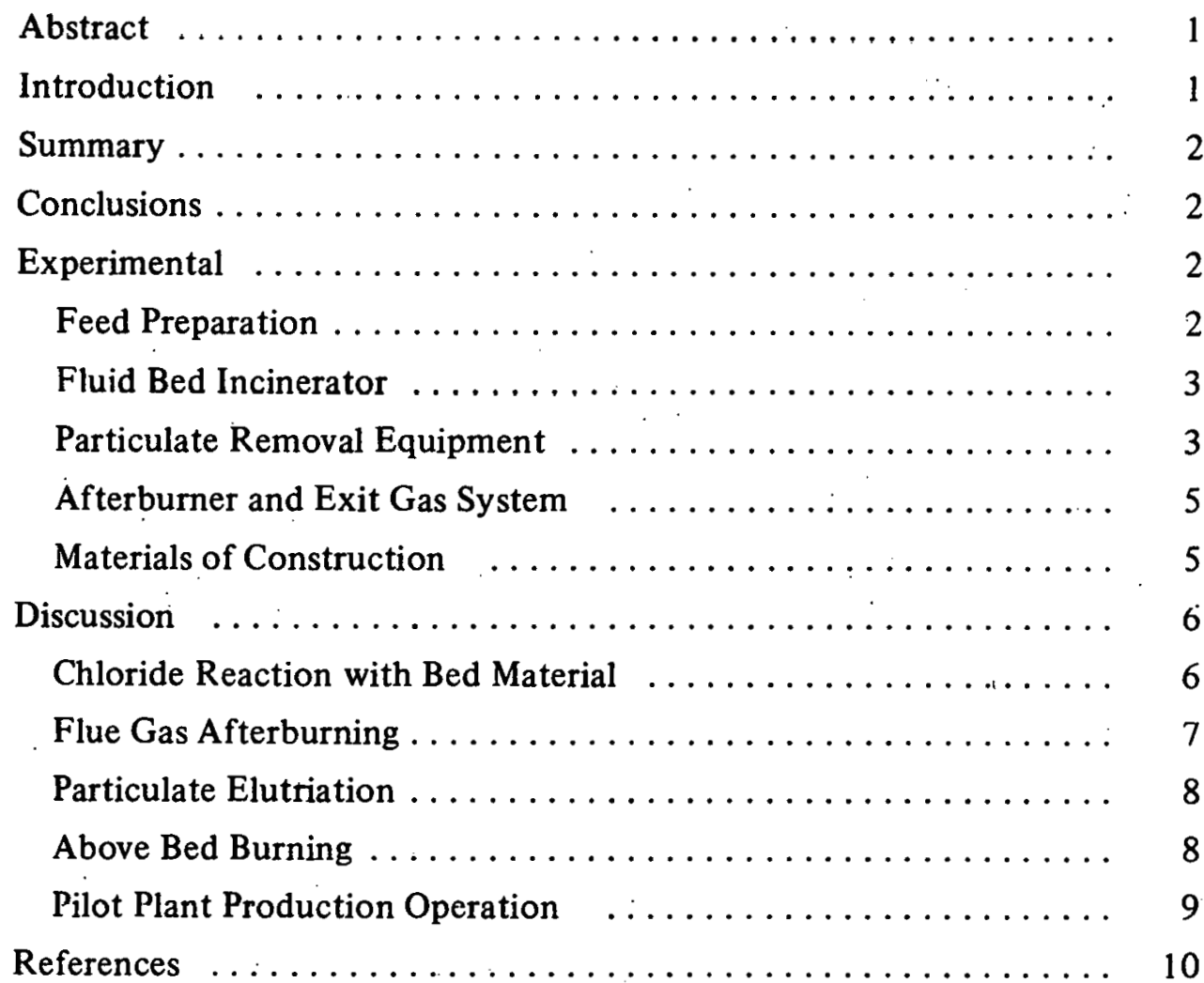


RFP-2271

\section{1}




\section{A C K N O W LEDGM EN T S}

The X-ray microscopy work was performed by H. L. Bramlet and H. M. Baker. P. T. Faccini provided engineering services for construction and many modifications of the pilot unit. The following people helped operate the pilot plant incinerator:
J. G. Avery
J. M. Benallo
D. A. Burton
F. E. Evans
H. N. Robinson 
RFP-2271 


\title{
PILOT PLANT DEVELOPMENT OF A FLUIDIZED BED INCINERATION PROCESS
}

\author{
Donald L. Ziegler, Andrew J. Johnson, Louis J. Meile, Alfred L. Johnston, and Elmer L. Shamhart
}

\begin{abstract}
Pilot plant scale tests have been made on a fluidized bed incineration process under development at the Rocky Flats Plant. The hydrogen chloride produced from combustion of chloridecontaining plastics reacts with sodium carbonate bed material in the primary combustion chamber. This minimizes equinment corrosion and climinates the need for aqueous scrubbing of the flue gas. A packed bed and a fluidized bed of oxidation catalyst were evaluated for low-temperature afterburning of the flue gas.
\end{abstract}

\section{INTRODUCTION}

A conventional, stationary incinerator at the Rocky Flats Plant has been in use for about 14 years to burn combustible residues containing recoverable concentrations of plutonium. This unit burns used material such as polyvinyl chloride (PVC) bags, polyethylene bottles, sheets, and bags, paper wipes, and polypropylene filter cartridges. The ash is processed by aqueous chemistry to recover plutonium. The incinerator operates at 800 to $1000^{\circ} \mathrm{C}$ and is manually fed bulk packages of waste materials. Flue gas from the unit passes through a series of heat exchangers to lower the gas temperature. It then goes through an aqueous scrubber to remove the acid gas and fly ash. The acid gas is primarily hydrogen chloride from decomposition of chloride-containing waste that has minor quantities of hydrogen fluoride (HF) and nitric acid $\left(\mathrm{HNO}_{3}\right)$.

The incinerator at the Rocky Flats Plant has been onc of the most successful incinerators operated at $\triangle E C$ facilities for combustion of radiodative contaminated residues, but the unit is presently in poor condition caused by corrosion of the metal shell. Some of the problems encountered in this opcration have been short refractory life (6 to 12 months), incomplete combustion of flue gas [carbon monoxide (CO) and soot], mechanical operation of the scrubber (complexity), and corrosion of the incinerator shell and scrubbing equipment (chloride attack). Because of these problems, which are common to many conventional inivinerallun processses, work was begun to develop an incineration process that would minimize or eliminate these problems. Laboratory studies ${ }^{1}$ determined the feasibility of burning waste in a fluidized bed of sodium carbonate. In this system, acid gases are reacted with the bed material, thereby minimizing corrosion of the incinerator and off-gas system. The in situ neutralization also makes possible the use of a dry off-gas system, eliminating the need for a complex aqueous scrubbing system and the subsequent processing of contaminated scrub solution.

The use of low-temperature $\left(400\right.$ to $700{ }^{\circ} \mathrm{C}$ ) afterburning makes possible a system that would not require refractory lining. This should decrease maintenance (for rebricking) and eliminate the costly and difficult process of recovering plutonium from used refractories. Cataly tic afterburning produces a minimum of carbon monoxide and unburned hydrocarbons or soot in the flue gas. Because of the low temperature $\left(550^{\circ} \mathrm{C}\right)$ used and uniform temperature obtained in the fluidized bed, the plutonium oxide produced in the ash should be more soluble than that produced in a conventional incinerator operating at 800 to $1000^{\circ} \mathrm{C}$.

Data from the laboratory tests were used to design a fluid bed pilot plant incinerator. The pilot plant was intended for evaluating process variables and obtaining process design information using noncontaminated waste materials. The unit could then be enclosed and tested with plutonium contaminated materials. All data presented in this report were generated with noncontaminated waste. 


\section{SUMMARY}

A pilot plant fluid bed incinerator with about $10 \mathrm{lbs} / \mathrm{hr}$ capacity has been constructed and operated to obtain process design information. A noncontaminated waste mixture of polyvinyl chloride (PVC), polyethylene, and paper has been used for the tests. The waste is chopped in a low-speed, cutter-type shredder and fed to the incinerator by a constant-pitch, tapered-screw conveyor. It is introduced into the primary combustion chamber under the surface of a fluidized bed of sodium carbonate $\left(\mathrm{Na}_{2} \mathrm{CO}_{3}\right)$ operating at about $550^{\circ} \mathrm{C}$. The hydrogen chloride generated by decomposition of the PVC reacts with the bed material. Tests indicate that essentially $100 \%$ of the chloride 15 reacted will the bed material up to a level of about $26 \%$ utilization of $\mathrm{Na}_{2} \mathrm{CO}_{3}$. Observation of the bed material by $\mathrm{X}$-ray microscopy revealed that a dense shell of sodium chloride $(\mathrm{NaCl})$ forms on the surface of the $\mathrm{Na}_{2} \mathrm{CO}_{3}$ particles, which tends to limit the chloride penetration of the core material.

A packed, catalytic afterburner was used to burn hydrocarbons in the flue gas. Room air was blended with flue gas in the afterburner to provide oxygen for combustion and to help carry away the heat of combustion. Because of fluidized bed material entrained with the flue gas, which could not be removed by a cyclone in the system, the packed bed of catalyst would normally become plugged and inoperable after about 48 hours of operation. Sintered metal filters were installed between the cyclone and the afterburner. Unburned hydrocarbon content of the flue gas at that point resulted in the filters becoming plugged with condensing tars. A fluidized bed of oxidation catalyst was evaluated for burning the flue gas prior to the particulate removal operation. This proved successful with good temperature control, complete combustion, and satisfaclury operation of the filters. The flue gas normally contains less than $1000 \mathrm{ppm}$ carbon monoxide and less than 800 ppm unburned hydrocarbons.

The system provides for the complete combustion process being accomplished below $650^{\circ} \mathrm{C}$, which negates the need for refractory lined equipment. The costly rebricking operation common to conventional incineration and the associated plutonium recovery from used refractories is therefore eliminated. Low tcmperature combustion should produce a more soluble form of plutonium oxide in the ash. Because of the high efficiency of chloride removal by the bed material, an aqueous scrubber will not be required for removal of acid gases. This makes possible a less complex flue-gas cleaning system and eliminates processing of aqueous scrub solution. In situ neutralization of the $\mathrm{HCl}$ should also minimize chloride corrosion of the incinerator and off-gas cleaning equipment.

\section{CONCLUSIONS}

1. Operating temperatures in the incinerator and afterburner are low enough to eliminate the use of refractories.

2. The performance of waste shredding and feeding of shredded material has been satisfactorily demonstrated:

3. Efficient $\mathrm{HCl}$ neutralization has been accomplished up to a level of about $26 \% \mathrm{Na}_{2} \mathrm{CO}_{3}$ utilization. This eliminates the need for an aqueous scrubbing system.

4. Catalytic afterburning produces a flue gas with minimal levels of unburned hydrocarbons.

\section{EXPERIMENTAL}

\section{Feed Preparation}

A low-speed, cutter-type shredder was purchased to grind materials for incineration. This unit has a rated capacity of about $14 \mathrm{yd}^{3} / \mathrm{hr}$, a capacity that far exceeds the pilot plant requirements. The unit is driven by a 10 -hp, high-torque electric motor. It is equipped with an over-torque device for protection from damage from tramp mctal that it cannot cut. This is a desirable feature because waste material could contain items such as bolts and wrenches. The cutting mechanism consists of cutter discs mounted on two parallel, horizontal shafts such that the cutters on one shaft intermesh with those on the other shaft. The two shafts 
rotate at different speeds ( 45 and $30 \mathrm{rpm}$ ) and in opposite directions so as to pull the waste down between the shafts. Waste on one disc is cut as it is forced against the back side of the cutters on the opposite shaft.

The waste was shredded and mixed to provide a known composition for the incinerator tests. The standard mixture consisted of $44 \%$ polyvinyl chloride (PVC), 28\% paper and $28 \%$ polyethylene. The known PVC content provided the basis for a chloride balance in the incinerator tests.

The shredder has been used to prepare about 4,000 lbs of waste. This material was passed through the shredder twice, using the 0.25 -in. thick cutters to provide a suitable feed size and uniformity of mixture of the waste components. The shredder has been down twice because of shaft failure. The motor drive shaft broke because a bolt that held the drive shaft in a support bearing came out. One main cutter shaft broke when the deflection of the 0.25 -in. thick cutter allowed the tooth to strike a disc on the other shaft. The shredder would be subjected to less severe conditions if waste was first shredded using 0.63 -in. thick cutters during the first pass and 0.25 -in. thick cutter for the second pass.

\section{Fluid Bed Incinerator}

The pilot plant reactor (incinerator) was designed to burn about $10 \mathrm{lbs} / \mathrm{hr}$ of waste. A flow diagram of the pilot unit is presented in Figure 1. The reactor provides for operation of a single fluidized bed or for operation with two fluidized bed in series. The lower or primary bed diameter is 14 in., which gives a bed cross-sectional area of about onc $\mathrm{ft}^{2}$. The upper or secondary bed is 16 in. in diameter or about a $1.3-\mathrm{ft}^{2}$, cross-sectional area. Above the second bed, the vessel diameter increases to $24 \mathrm{in}$., which provides for a reduction of gas velocity. This reduction permits the return of some cntrained particulates to the bed. The gas exits the reactor through a 4-in. diameter cyclone that removes more of the entrained solids.

The reactor was equipped with a screw conveyor for feeding bed material to the second bed. An overflow tube and air-jet ejector were tested to convey upper bed material to the primary bed. An overflow tube was also used to remove excess lower bed material.

The shredded waste was fed from a hopper by a chain conveyor used to regulate the waste feed rate. The waste then passed through a constantpitch, tapered-screw conveyor that served to introduce feed to the primary bed under the surface of the fluidized bed material. A third conveyor was provided for feeding bed material via the tapered screw conveyor to the primary chamber.

Air, nitrogen, and steam were available for fluidization use. Steam has not been used in any of the experiments. Tests have been made with $100 \%$ nitrogen (pyrolysis), 100\% air, and various mixtures of air and nitrogen. Fluidizing gas is passed through an electrical heater until the bed material reaches about $300^{\circ} \mathrm{C}$. At that point, waste can be used to bring the reactor up to the desired operating temperature of about $550^{\circ} \mathrm{C}$.

\section{Particulate Removal Equipment}

For many of the tests, flue gas from the cyclone was taken directly to the afterburner, but the cyclone did not remove about 20 to $30 \%$ of the dust in the flue gas because of the extremely fine particle size. After several hours of operation, dust would plug the packed bed afterburner, and the test would have to be terminated. The time required to plug the afterburner was ex tended by using a more open support plate so the dust could work up into and partially through the bed.

Because of this dust problem, many tests were made in which the upper chamber was packed with a bed of alumina balls functioning as a roughing filter. Sintered metal filters were ordered for installation downstream from the cyclone to remove dust prior to afterburning. Other methods of dust removal were also tested on the pilot unit and at the manufacturer's facilities. The filter system installed consisted of seven, sintered-metal filter tubes of 0.75 -in. diameter in each of five separate filter holders. Each filter holder was piped in 
FIGURE 1. Flow Diagram for Pilot Plant Fluid Bed Incinerator.

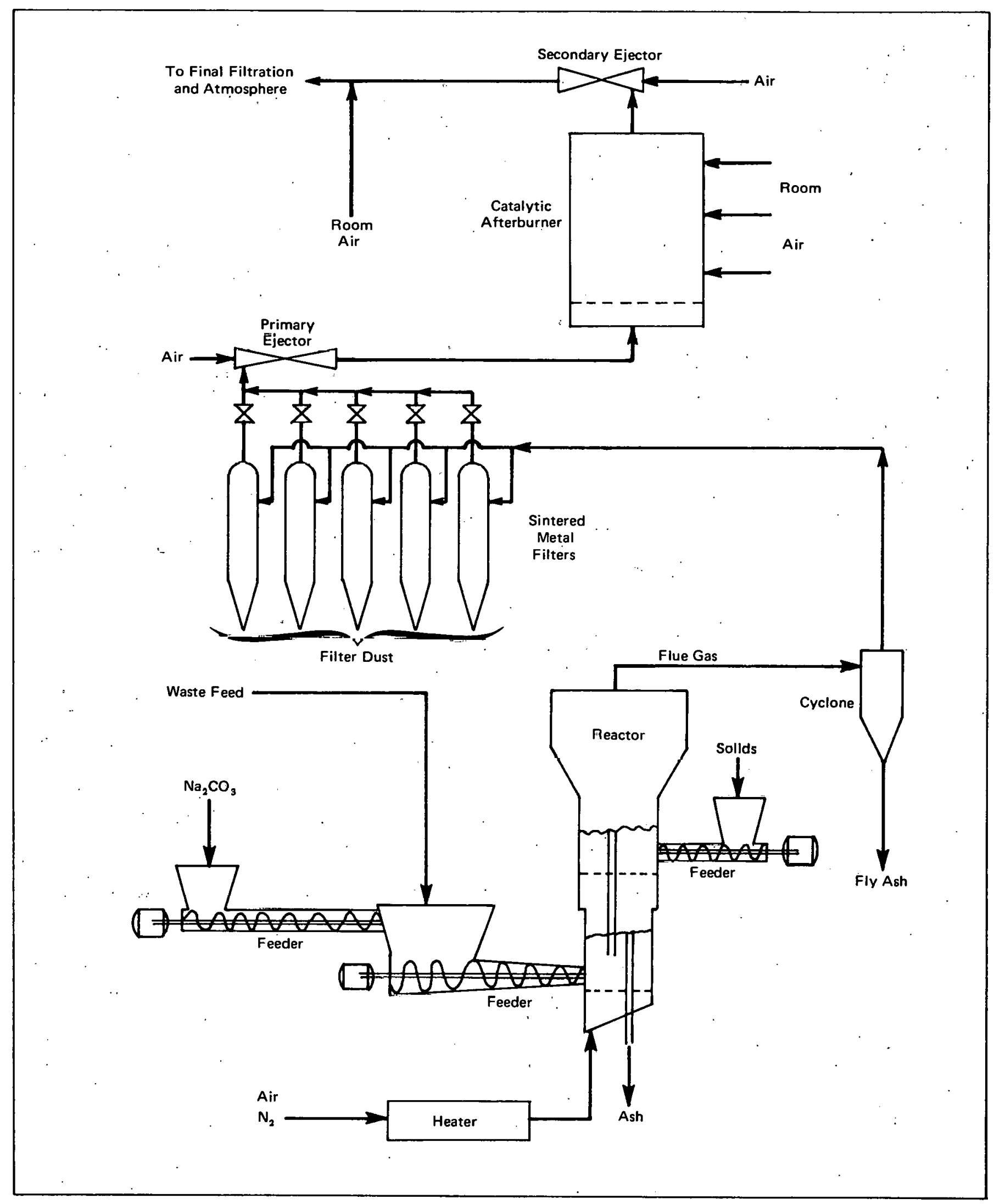


parallel so the exit flow from one holder could be stopped and the flow reversed to remove collected dust while flue gas continued flowing through the other filter tubes. This procedure could then be repeated for each of the other filter tubes.

\section{Afterburner and Exit Gas System}

An air-jet ejector was used downstream of the filters to provide the motive force for gas flow through the reactor and filter system. The ejector was adjusted to provide atmospheric or slightly below atmospheric pressure in the reactor at the point where waste was introduced to the primary chamber. This provided for minimal air in-leakage with the feed. The air-jet ejector also provided oxygen needed for combustion in the afterburner.

From the ejector, flue gas passed up through a packed bed catalytic afterburner. The afterburner was $2 \mathrm{ft}$ in diameter by 3 -ft long. Additional air needed for combustion and cooling was admixed with the process gas stream at three levels in the afterburner. This was room air pulled in by the negative (below atmospheric) pressure in the unit. A secondary air-jet ejector at the exit of the aftcrburner provided the molive force for the gas flow pressure drop through the afterburner. The air-jet ejectors were selected for this application because they could withstand the high operating temperature (up to $700{ }^{\circ} \mathrm{C}$ ).

A fan was initially tried downstream of the afterbumer after the flue gas had been mixed with a large amount of room air for cooling. The fan was removed because it did not provide sufficient pressure differential for flow through the equipment. A second problem with the fan was possible pressurization of the filter plenum resulting from malfunctioning controls. An example would be if the plenum flow stopped and the incinerator continued operating. This possibility is eliminated with the use of ejectors, which operate only on flue gas and not on room exhaust. Normally, negative pressure on the plenum is used to blend the flue gas with a large amount of room air. If the plenum flow should stop, the flue gas would automatically go to the room. The flue gas goes through one stage of high efficiency particulatc air
(HEPA) filtration before it leaves the incinerator room. It then passes through four stages of HEPA filtration before reaching the outside atmosphere.

\section{Materials of Construction}

The pilot plant incinerator system was constructed primarily of Hastelloy® C276 and 304 stainless steel. These and other construction materials used for the system are listed in Table 1. A test rack of

TABLE 1. Construction Materials for Pilot Plant Fluid Bed Incinerator.

\begin{tabular}{|c|c|}
\hline Component & Material \\
\hline \multicolumn{2}{|l|}{ Reactor } \\
\hline Primary Bed Section & 304 Stainless Șteel \\
\hline Primary Distributor Plate & Hastelloy@C276 \\
\hline Secondary Bed Section & Hastelloy C276 \\
\hline Secondary Distributor Plate & 304 Stainless Steel \\
\hline Cap & 304 Stainless Steel \\
\hline Inlet Plenum & Hastelloy C276 \\
\hline Thermowells & 304 Stainless Steel \\
\hline Cyclone & 304 Stainless Steel \\
\hline Air Preheaters & Hastelloy. C276 \\
\hline \multicolumn{2}{|l|}{ Sintered Metal Filters } \\
\hline Filter Chambers & 304 Stainless Steel \\
\hline Filters & 316 Stainless Steel \\
\hline Primary Ejector & 304 Stainlesss Steel \\
\hline \multicolumn{2}{|l|}{ Afterburner } \\
\hline Chamber & Hastelloy C276 \\
\hline Distributor Plate & Hastelloy C276 \\
\hline Bottom End Plate & 304 Stainless Steel \\
\hline Top End Plate & 304 Stainless Steel \\
\hline Air Inlet Tubes & 304 Stainless Steel \\
\hline Secondary Ejector & Hastelloy X \\
\hline Interconnecting Piping & $\begin{array}{l}\text { Hastelloy C276 and } \\
304 \text { Stainless Steel }\end{array}$ \\
\hline Room and Process Exhaust System & $\begin{array}{l}\text { Carbon Steel and } \\
\text { Stainless Steel }\end{array}$ \\
\hline \multirow[t]{8}{*}{$\begin{array}{l}\text { Corrosion Test Coupon } \\
\quad \text { (in primary bed) }\end{array}$} & Hastelloy X \\
\hline & Hastelloy C.276 \\
\hline & Inconel 600 \\
\hline & Inconel 690 \\
\hline & Incoloy 800 \\
\hline & 304L Stainless Steel \\
\hline & 321L Stainless Steel \\
\hline & 316L Stainless Steel \\
\hline
\end{tabular}


various metal coupons has been installed in the primary fluidized bed. These metals will be evaluated for suitability as material for constructing fluid bed incineration equipment. A preliminary evaluation indicates that Hasetlloy C276 exhibits excellent corrosion resistance, and only minor corrosion was determined for 304 stainless steel in areas where the temperature does not exceed $600{ }^{\circ} \mathrm{C}$. Materials used in the pilot plant equipment were exposed to more severe conditions than would normally be encountered in the production process. This exposure resulted from evaluating a wide range of variables. Hastelloy C276 is expected to be satisfactory; however, other less expensive materials may also be suitable for this application.

\section{DISCUSSION}

\section{Chloride Reaction with Bed Material}

A major objective of this process is neutralizing $\mathrm{HCl}$ at the point of generation. This would eliminate the need for flue gas scrubbing to remove acid gases. To accomplish this, chloride-containing waste is burned in a bed of sodium carbonate that reacts with the $\mathrm{HCl}$ to produce sodium chloride. The chloride is thus removed from the system without the complexity of a scrubbing system. This process also minimizes chloride corrosion of the equipment.

The efficiency of chloride removal or reaction as a function of the efficiency of sodium carbonate usage has been evaluated in several experimental runs on the pilot unit. Presented in Figure 2 are the results of neutralization efficiency for experiments conducted with continuous waste feeding to a single bed of $\mathrm{Na}_{2} \mathrm{CO}_{3}$. For these tests, fresh $\mathrm{Na}_{2} \mathrm{CO}_{3}$ was continuously fed to, and bed material continuously discharged from the fluidized bed. Fssentially $100 \%$ efficiency of $\mathrm{HCl}$ reaction was obtained up to a level of about $26 \% \mathrm{Na}_{2} \mathrm{CO}_{3}$ utilization. The chloride reaction efficiency decreases and significant quantities of $\mathrm{HCl}$ are released with the flue gas after this point.

The data were generated with 500- to $1000-$ micrometre size ( 16 to 32 mesh) sodium carbonate bed material. Analysis, by X-ray microscopy, of

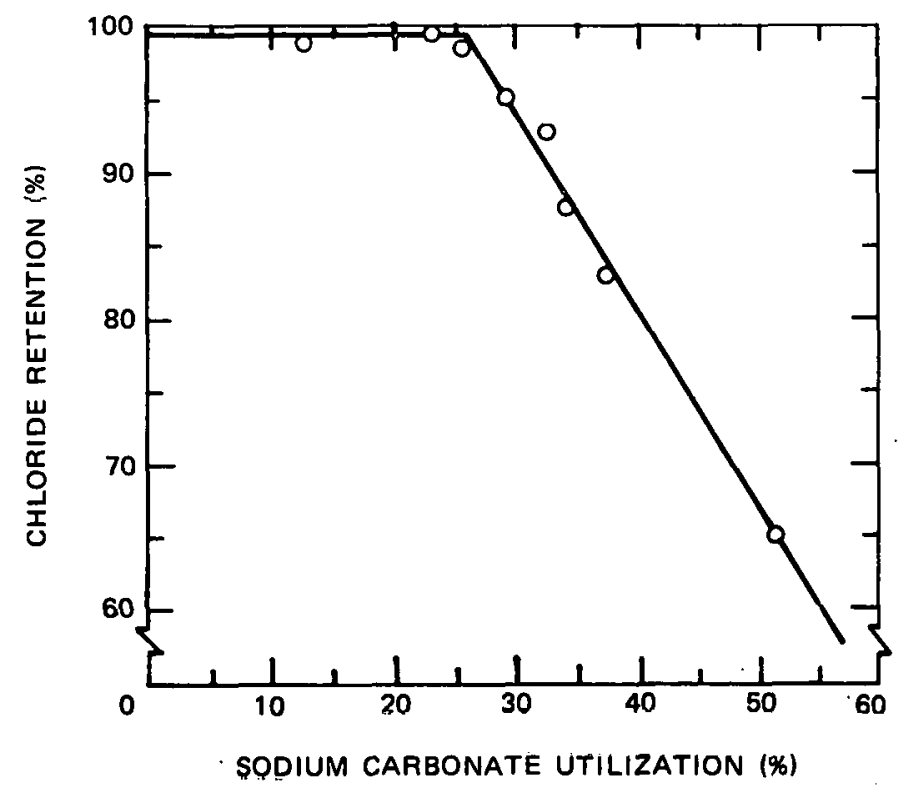

FIGURE 2. $\mathrm{HCl}$ Reaction Efficiency for Continuously Operated Fluid Bed.

the used bed material indicates that the particles are composed of a dense shell (high concentration of $\mathrm{NaCl}$ ) surrounding a core of unreacted $\mathrm{Na}_{2} \mathrm{CO}_{3}$. $A$ cross section of an unreacted sodium carbonate bead is presented in Figure 3. This micrograph shows the material is quite porous with some large volus. A iniciugraph of a cross 30 ctioned bead that had been reacted in the fluid bed incinerator is presented as Figure 4. It shows the dense shell formed around core material. The chlorine $\left(\mathrm{K}_{a}\right)$ $\mathrm{X}$-ray image of the same bead showed a high concentration of sodium chloride in the shell. Figure 5 is a micrograph of a second reacted bead. The chlorine $\left(\mathrm{K}_{a}\right)$ X-ray image again identified a high concentration of sodium chloride in the dense outer shell.

The formation of a dense shell of sodium chloride around the core sodium curbonate indicates that smaller particles would improve the neutralization efficiency at higher levels of $\mathrm{Na}_{2} \mathrm{CO}_{3}$ utilization. This also suggests that abrasion of the $\mathrm{NaCl}$ shell to expose the core $\mathrm{Na}_{2} \mathrm{CO}_{3}$ may improve $\mathrm{Na}_{2} \mathrm{CO}_{3}$ utilization. 


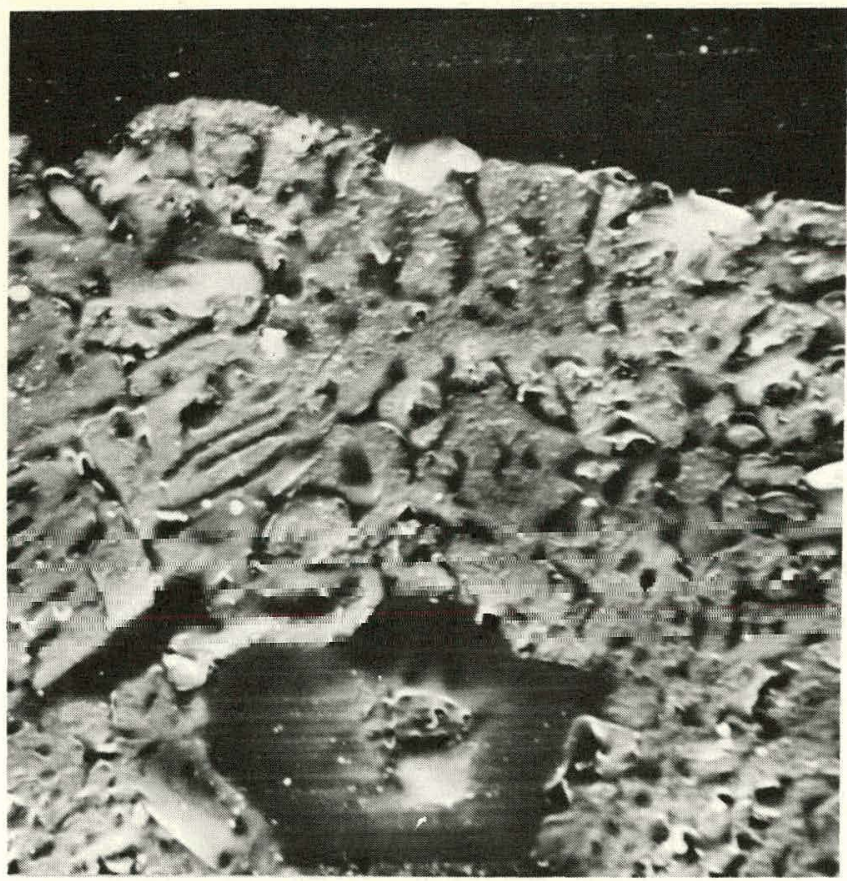

FIGURE 3. Micrograph of Unreacted Sodium Carbonate Bead. Magnification 100X.

Presented in Figure 6 are data generated with batch operation of bed material and continuous feeding of the waste. No $\mathrm{Na}_{2} \mathrm{CO}_{3}$ was fed nor bed material discharged during the test. All data represented by the lower line were generated without interruption of the tests. Data represented by the other line were generated by runs that were interrupted during the test. For these runs, the bed material was reacted to an intermediate level of $\mathrm{Na}_{2} \mathrm{CO}_{3}$ utilization, the bed material cooled to room temperature and then reheated and carried to completion of the test. This intermediate cooling and reheating increases the neutralization efficiency at equivalent utilization levels. This could be caused by thermal stress cracking of the sodium chloride shell and partial exposure of the core $\mathrm{Na}_{2} \mathrm{CO}_{3}$. Both of these lines intersect the $100 \%$ chloride retention level at about $26 \% \mathrm{Na}_{2} \mathrm{CO}_{3}$ utilization.

The fluidized bed depth did not have a significant effect on neutralization efficiency. Data from deep and shallow bed experiments are included in

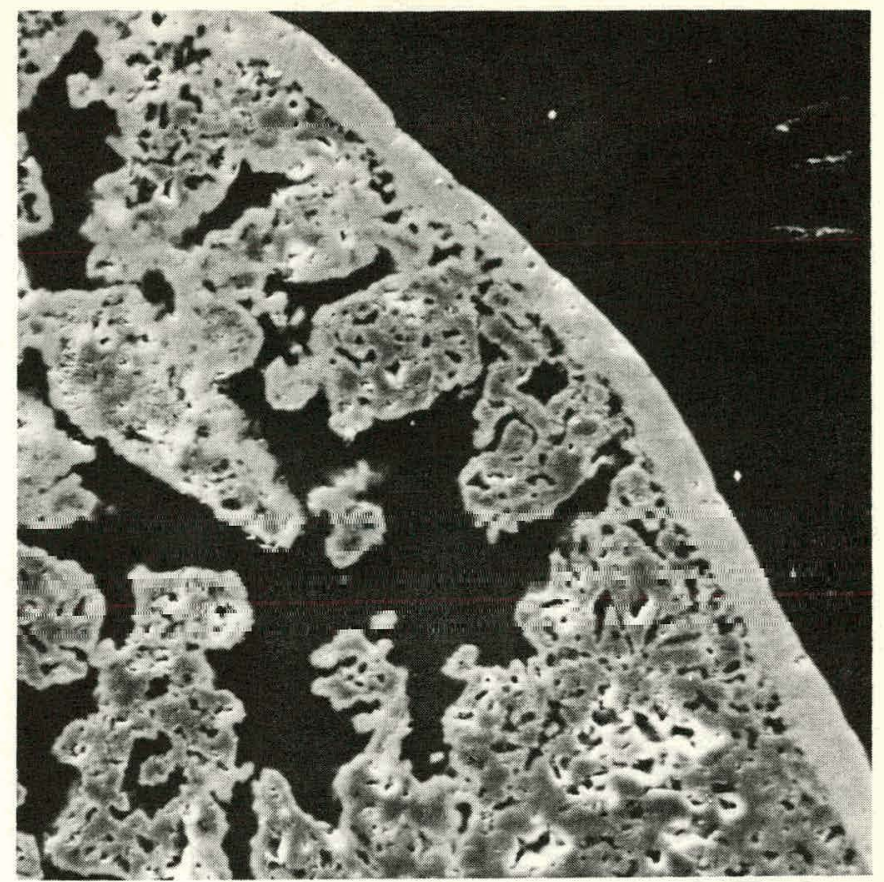

FIGURE 4. Micrograph of Reacted Sodium Carbonate Bead with Shell of Sodium Chloride. Magnification 300X.

Figures 2 and 6 . These data suggests that the $\mathrm{HCl}$ is generated and reacted shortly after waste is introduced. Several tests were made using a secondary bed of $\mathrm{Na}_{2} \mathrm{CO}_{3}$. The secondary bed did not improve the neutralization efficiency at comparable $\mathrm{Na}_{2} \mathrm{CO}_{3}$ utilization levels. This supports the theory of rapid $\mathrm{HCl}$ generation and neutralization.

Flue gas from the incinerator has been analyzed for chloride content during these tests. Data on batch bed tests confirm an increase in chloride content when the bed exceeded $26 \% \mathrm{Na}_{2} \mathrm{CO}_{3}$ utilization. A plot of chloride content in the flue gas is presented in Figure 7. The chloride content increased rapidly at a point equal to about $30 \%$ $\mathrm{Na}_{2} \mathrm{CO}_{3}$ utilization in the bed.

\section{Flue Gas Afterburning}

When the gas was filtered prior to the afterburner, to remove elutriated bed material, the sintered metal filters became plugged with condensing 


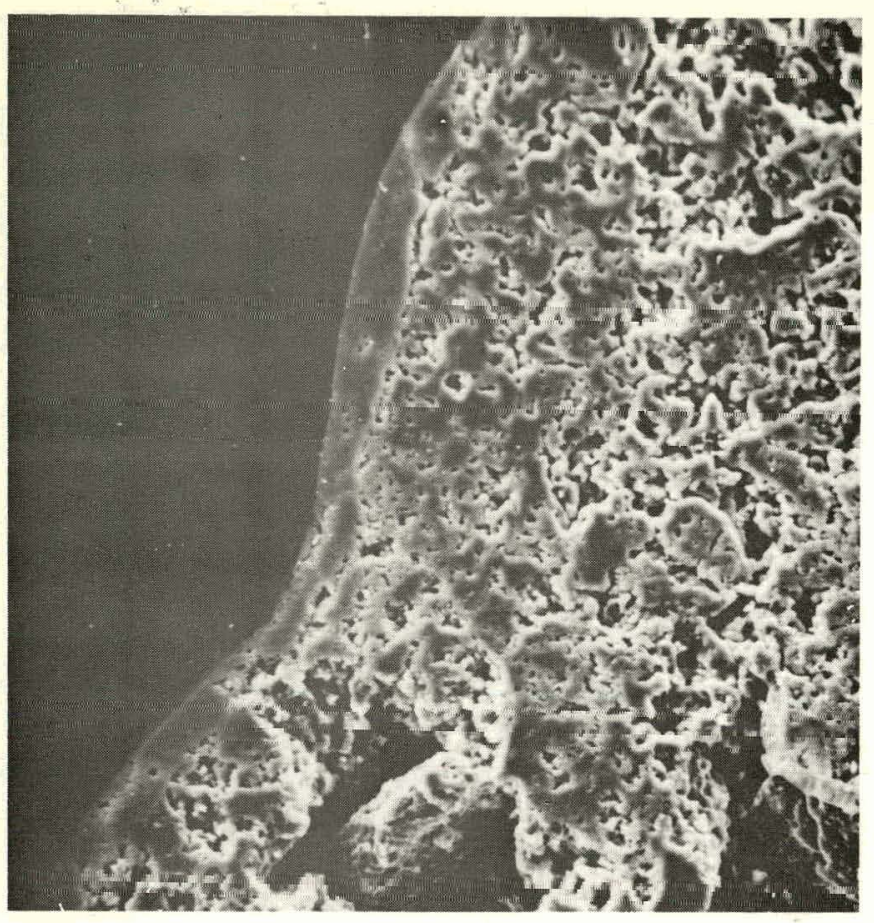

FIGURE 5. Micrograph of Reacted Sodium Carbonate with Sodium Chloride Shell. Magnification 300X.

hydrocarbons or tars. Because of this filtration problem, tests were conducted with a fluidized bed of oxidation catalyst in the secondary chamber of the incinerator. 'I'his allowed particulates to percolate through the catalyst bed and the filtration to be performed on a gas stream free of significant concentrations of hydrocarbons.

Cataly tic oxidation provides several important features for this process. The catalyst is effective at lower temperatures than are required for open flame afterburning. Therefore, the elutriated bed material will not be melted and coated on reactor walls, which could occur in conventional open flame afterburning. Low temperature operation of the catalyst also eliminates the need for refractory lined equipment. The catalyst is effective in producing a high quality flue gas. Typical flue-gas compositions for the fluidized bed and packed bed operation are presented in Table 2.

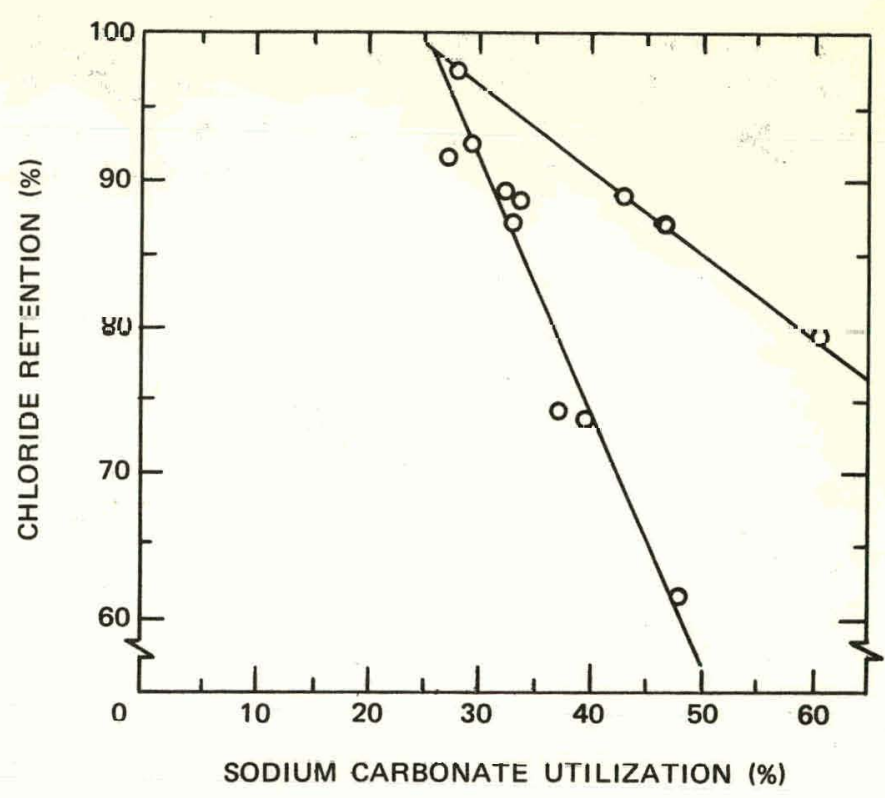

FIGURE 6. HCl Reaction Efficiency for Batch Operated Fluid Bed.

\section{Particulate Elutriation}

Most of the generated ash is elutriated from the bed and collected in cyclone and filtration system. The majority of tests resulted in 70 to $80 \%$ of the ash being elutriated from the bed. The remaining 20 lu $30 \%$ of the ash was removed with the bed material.

With the fluidized catalytic bed afterburner, some of the catalyst is elutriated from the reactor. The rate of catalyst loss is dependent on gas fluidizing velocity and the mesh size of the catalyst used. These data are presented in Figure 8. This type of information is needed for properly sizing the fluidized bed afterburner to minimize catalyst usage.

\section{Above Bed Burning}

A mixture of air and nitrogen is normally used as the fluidizing gas. Nitrogen is used to prevent open flame burning of vapors above the bed. Overheating 


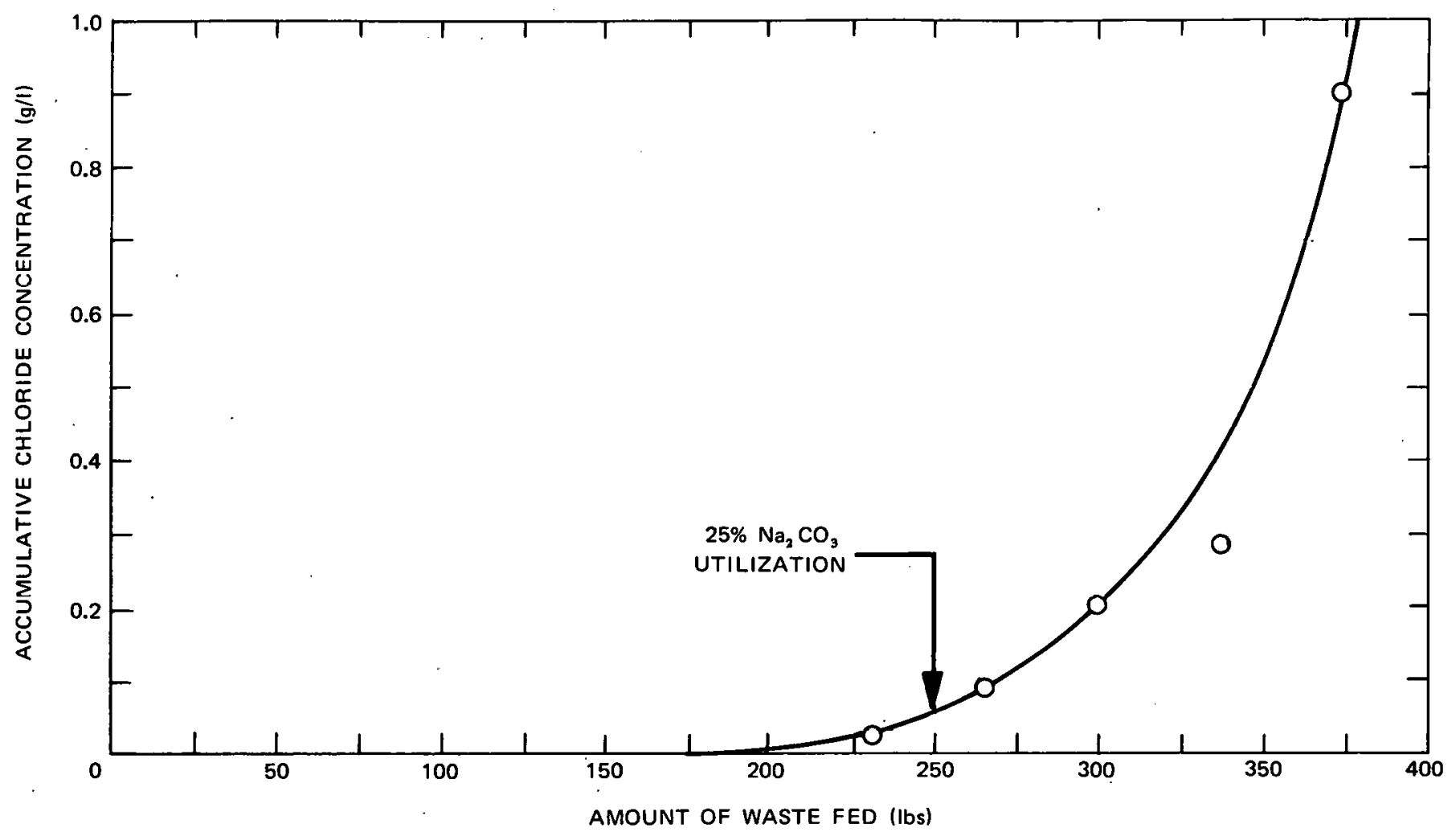

FIGURE 7. Off-Gas Chloride Analysis, 50-Inch Bed, Pilot Plant Incinerator.

TABLE 2. Typical Flue-Gas Composition Exiting Afterburner.

\begin{tabular}{lccc} 
& Packed Bed & & Fluidized Bed \\
\cline { 2 - 2 } Oxygen (\%) & & & 7.8 \\
Carbon Dioxide (\%) & 8.3 & & 8.3 \\
Carbon Monoxide (ppm) & 800 & & 770 \\
Total Hydrocarbons (ppm) & 800 & & 640
\end{tabular}

entrained bed material causes partial melting of material and plugging of the upper distributor plate. Additional air is required in the catalyst to complete combustion of vapors in the flue gas. For the tests reported, this air was introduced in the space above the primary bed; however, back mixing of the air with vapors exiting the bed has resulted in increasing the above bed, open flame burning. Tests are now in progress that will utilize air addition directly into the catalyst rather than below the distributor plate. This should eliminate the above bed burning.

\section{Pilot Plant Production Operation}

All tests performed on the pilot plant have been made with noncontaminated waste materials. The unit is being modified to allow operation with contaminated materials. Two shredders in series will be used to chop the bulk feed material. The first unit will have 0.63 -in. thick cutters; the second stage will use 0.25 -in. thick cutters. These units will utilize a hydraulic drive system that should extend equipment life and will provide for wider flexibility of operation. The feed chain conveyor will be removed and a variable speed 


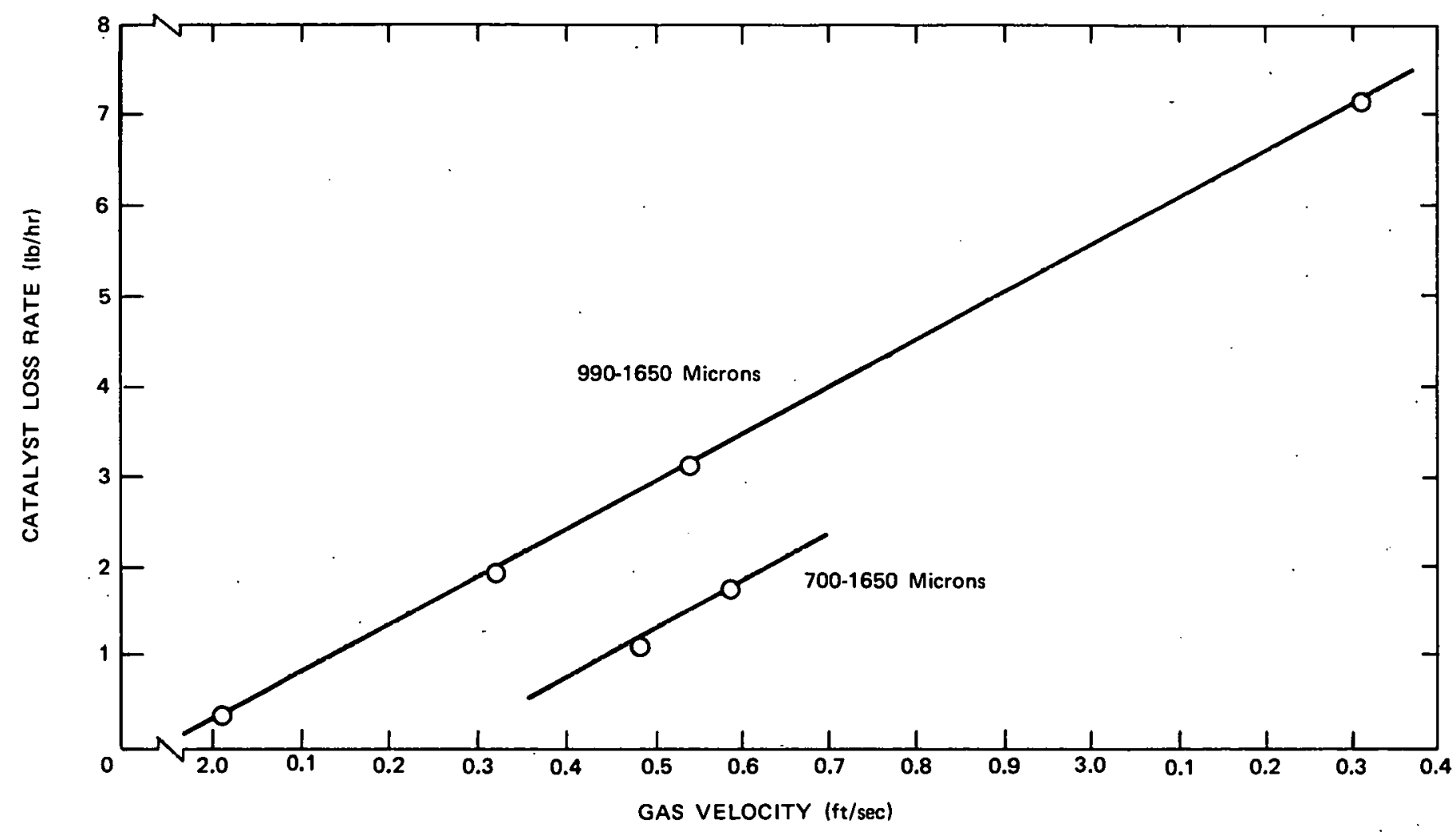

FIGURE 8. Effect of Gas Velincity on Catalyst Elutriation. -

drive on the tapered screw conveyor will be used to regulate waste feed rate.

The reactor will be modified to increase the capacity to about $19 \mathrm{lbs} / \mathrm{hr}$. This will be accomplished primarily by installing the 24-in. diameter catalyst chamber on the reactor for use as the secondary fluidized bed section. A 16-in. diameter section will be used as the primary chamber containing a $\mathrm{Na}_{2} \mathrm{CO}_{3}$ fluidized bed. A new, upper distributor plate will be used that will introduce air directly in to the catalyst. This addition of air is required for secondary combustion. The sintered metal filter area will be increased by $40 \%$, and a single air-jet ejector will be used downstream of the filters.
The equipment will be enclosed in a room, called a canyon, with single-side, glove-port access. The unit will be operated by personnel from outside the canyon. All major maintenance will be performed within the canyon by personnel in pressure suits.

\section{REFERENCES}

1. D. L. Ziegler, A. J. Johnson, and J. L. Meile. Fluid Bed Incineration. RFP-2016. Rocky Flats Division, Dow Chemical U.S.A. June 1973. 